\title{
Transnational aging: toward a transnational perspective in old age research
}

\author{
Vincent Horn $^{1} \cdot$ Cornelia Schweppe $^{1}$
}

Published online: 28 October 2017

(c) Springer-Verlag GmbH Germany 2017

Innovations in transportation and communication technologies have led to an increasingly globalized and interconnected world. The resulting compression of time and space has not only changed the world economy, but it has also had a profound impact on people's everyday social life. People are now able to stay in real-time virtual contact with globally dispersed others, share images with a few clicks, obtain information instantaneously, etc. At the same time, travel infrastructures improved and airline tickets became affordable for a wider population. Consequently, back-andforth movements between different countries are no longer reserved for a small elite. For the first time in history, people are able to be socially present in different locations, more or less simultaneously. Migration scholars introduced the transnational perspective to describe and conceptualize the various relations (e.g., social, economic, political) individuals and communities develop and sustain across geographical distances and national borders (Faist 2000; Glick Schiller et al. 1992). Soon the use of this concept spilled over to other social science disciplines, contributing to the emergence of a new multidisciplinary field of transnational studies (Khagram and Levitt 2008).

However, researchers studying aging have been comparatively hesitant to establish a transnational research agenda (Philipson and Ahmed 2004; Torres 2013). The principal reason for this reluctance is the ongoing dominance of "methodological nationalism" (Wimmer and Glick Schiller 2002) in aging research (Toyota and Xiang 2012).

Responsible editor: H.-W. Wahl

Vincent Horn

hornv@uni-mainz.de

1 Johannes Gutenberg Universität Mainz, Mainz, Germany
Methodological nationalism refers to the naturalization of nation-states by the social sciences, which for a long time equated society with the nation-state and considered national borders as the natural unit of study (Wimmer and Glick Schiller 2002). Such territorial-bounded thinking is also embedded in one of the focal concepts used in this field by researchers and policy makers alike: aging in place. Accordingly, concepts, research questions, hypotheses, data collection and conclusions are drawn from within a framework that assumes a quasi-natural overlap between a territory and an individual's social space (Zhou 2012). As a consequence, theoretical premises and methodological approaches to aging continue to overlook dimensions in older people's lives that go beyond the border and boundaries of a defined (national) territory.

The concept of transnational aging can serve as a methodological lens for studying these transnational dimensions in old age (Horn et al. 2013; Horn and Schweppe 2016). Defined as the "process of organizing, shaping, and coping with life in old age in contexts which are no longer limited to the frame of a single nation state" (Horn et al. 2013: 7), transnational aging cuts across many themes relevant for aging research (e.g., everyday practices, biographies, family relationships, social services, well-being, social policy) and provides an approach to expanding and revising the theoretical landscape. This includes, for example, theories in social gerontology (e.g., life course perspective), ecological theories (e.g., aging in place) or theories of identity (e.g., intersectionality perspective).

Several developments indicate that transnational processes in old age will gain relevance in the future: (1) the aging of migrant populations in many industrialized countries; (2) the increasing trend of international retirement migration; and (3) the growing number of older people who experience the emigration of close relatives. The four papers 
presented in this special issue examine these developments from different theoretical and methodological angles. They are part of the outcome of the International Symposium "Organizing Aging Transnationally and its Social Implications," March 12-13, 2015, organized by the Transnational Aging Research Cluster at the Institute of Education, University of Mainz (Germany).

\section{Aging migrant populations}

During the last decades, the number of migrants reaching retirement age in industrialized countries has increased significantly (Leach 2008; White 2006). The majority of studies on aging migrant populations focuses on their vulnerabilities originating from the risks of migration and the accumulation of disadvantages through their life course (Dwyer and Papadimitriou 2006). Accordingly, these studies tend to examine the stressors older migrants encounter in their country of residence and to analyze the relationships between ethnicity and social disadvantages (Baykara-Krumme et al. 2012). Given this focus, cross-border aspects and dimensions of aging migrants' lives often go unnoticed (Ciobanu et al. 2017).

However, a growing body of the literature can be found which approaches aging migrants from a transnational vantage point. This literature reveals that older migrants engage in a variety of transnational practices, including the maintenance of close ties with friends and relatives in their country of origin, the cross-border utilization of healthcare services and the development of transnational identities through different forms of belonging to their earlier and recent communities (Baykara-Krumme 2013; Bolzman et al. 2017; Smith Nielsen et al. 2012). Questions of belonging have been relevant to transnational studies since their very beginning and are increasingly taken up by transnational aging scholars. Drawing on Levitt and Glick Schillers' (2004) differentiation between "ways of being" and "ways of belonging," Zontini (2015) shows that although transnational practices ("ways of being") may diminish with advanced age (e.g., because of reduced mobility), the same does not apply to identities and sense of self ("ways of belonging"). Constructions of self and identity result from connections to different locales, but the association between transnational belonging and older people's emotional well-being has still remained unexplored.

In their paper, Klok et al. (2017, in this issue) address this gap by exploring whether a sense of belonging functions as a protective mechanism against loneliness among older Turkish and Moroccan migrants in the Netherlands. Adding a transnational dimension to Berry's (1980) model of acculturation, they find that a sense of transnational belonging leads to poorer well-being. The article follows a quantitative approach using data from the Longitudinal Aging
Study Amsterdam (LASA) of older migrants aged 55-66. Thus, it also contributes to the methodological diversity in transnational research, which-to a large degree-is based on qualitative research designs.

Most literature on aging migrants' transnational entanglements emphasizes the persisting power and significance of the nation-state. For example, social security systems, which in many ways are shaped by national states, have an important impact on the temporal and spatial dimensions of older migrants' transnational involvement as they are influenced by the access and portability of social security entitlements across countries. Thus, for example, the question of whether pensions can be received in another country than the country of residence have a bearing on the older migrants' decision whether to join their children abroad, to stay in the country of residence or to develop pendular migration patterns (Bolzman et al. 2006; Lunt 2009). Still, the portability of social security rights is a complex issue due to differences between social security systems, formal hurdles related to access requirements and administrative discretion, especially in the interpretation of residency rules (Avato et al. 2010). Therefore, older people often develop residential strategies in order to maintain access to social benefits and services in the receiving country. These strategies are particularly relevant in case of healthcare services and means-tested benefits, such as old age pensions. Indeed, from a classical welfare state perspective, extending the eligibility for means-tested entitlement programs to older people moving outside the national territory seems to contradict their national development and foundations (Mishra 2000).

However, Böcker and Hunter (2017, in this issue), in their paper, show that the Dutch and French governments have taken steps to break this link between solidarity and territorially bounded consumption of welfare, by providing lifelong income security for older migrants who return to countries of origin on a permanent or semi-permanent basis. The paper asks for the motivation of policy makers initially developing these novel policy tools. Based on interviews with key stakeholders and available official documents, Böcker and Hunter show that in both France and the Netherlands, policy makers' initial motivations can be characterized as rather benign, if not beneficent: to facilitate return for those who are willing but unable to afford it. However, two types of obstacles impeded the implementation of these policies. One, non-discrimination clauses and free movement rights in EU law make it difficult to implement particularistic policies that benefit a specific category of older people. And two, widespread anti-migrant attitudes in the two countries promise little opportunity to gain votes with migrant-friendly measures. With first-generation aging migrants gaining demographic weight, the question of how to secure/better their welfare transnationally is likely to gain more and more importance. 


\section{International retirement migration}

Another increasingly widespread mobility trend in old age is international retirement migration. The term usually refers to the movement of older people from the Global North to countries with better climate, extended leisure options, lower living costs and attractive landscapes (Casado-Díaz et al. 2004; King et al. 2000). Research in this field emerged in the 1990s and has primarily focused on the so-called life-style migration of Northern European retirees, especially to Spain. These studies emphasize that international retirement migration is often not migration in the classical sense (Nokielski 2005). Older people do not relocate their residence permanently abroad, but rather tend to move frequently between their countries of destination and origin, develop transnational lifestyles and identities, engage in transnational social, cultural and political activities and maintain relationships with friends and family members in their earlier communities (Gustafson 2008; O'Reilly 2000). In addition, researchers have addressed questions related to the retirement migrants' access to and use of health and long-term care services in their new environments (Ackers and Dwyer 2002; Blaakilde 2014; Hall and Hardill 2016; La Parra and Angel 2008).

More recently, a diversification of destinations for international retirement migration can be observed. New focal points are emerging in Africa (Chege 2014), Latin America (Hayes 2015; Lardiés-Bosque et al. 2016) and Southeast Asia (Husa et al. 2014; Ono 2008; Toyota 2006; Wong and Musa 2015). In contrast to life-style migration, the older peoples' hope for the resolution or alleviation of currently perceived or anticipated personal strains and problems appears to be a core characteristic for this kind of mobility (Bender et al. 2014; Hayes 2015; Toyota and Xiang 2012). This includes financial problems due to low pensions, as well as social isolation or long-term care needs. Indeed, the establishment of old age facilities for German-speaking older people in South East Asian and Eastern European countries can be seen as a response to the care deficit in Austria, Germany or Switzerland (Bender et al. 2017a). While some academic attention has been paid to the sociopolitical context of this phenomenon (Horn et al. 2016), little is known about the processes that explain the organizationspecific configurations of such facilities.

Bender et al. (2017b, in this issue) address this very issue. Their paper presents findings from an ethnographic study of old age care facilities for German-speaking people in Thailand. It analyses the conditions and processes behind the development and specific configurations of old age care facilities for German-speaking people in Thailand. The authors argue that even though transborder processes at the socio-structural level are important backdrops for the emergence of these facilities (e.g., the possibility to transfer pensions from German-speaking countries to Thailand or the Thai policies that facilitate retirement migration), they are not sufficient to explain the specific configuration of these facilities at the local level. In this regard, they point out the central role played by the facility operators as transnational actors who mediate between the countries and the various groups of actors (e.g., residents, staff, relatives and neighborhood) involved in these facilities. The authors conclude that the processes of mediation and intertwining are important and distinctive features of the emergence of these facilities, necessitated by the fact that although the facilities are located in Thailand, their "markets" are in the Germanspeaking countries of their target groups.

\section{Emigration of young people}

Despite multiple differences, for example regarding their motivations, ethnicity etc., aging and retirement migrants share the experience of having moved to another country. However, it is not only older people with migration histories who are involved in or affected by transnational processes. Given the increasing international migration of younger people, a growing number of older people in the sending countries experience the emigration of (some of) their descendants. One strand of studies on older family members "left behind" points to the dependencies and vulnerabilities caused by their children's emigration (King and Vullnetari 2006; van der Geest et al. 2004). Another strand of research emphasizes how, with sometimes enormous efforts, the emigrated children strive to comply with intergenerational norms of reciprocity, for example by sending remittances or providing emotional support via Skype or telephone (Baldassar et al. 2007). Older family members in the country of origin are not just passive receivers of transnational support. They actively contribute to the transnational family's wellbeing through transforming their role as parents and grandparents according to the new circumstances. Older women in particular engage in more or less frequent travels to their children's country of residence, sometimes for extended periods (Deneva 2012; Lie 2010).

Besides visits, phone calls and the sending of gifts and money, new information and communication technologies (ICTs) have become constitutive modes of transnational grandparenting (Baldassar et al. 2017). There is a general consensus that ICTs have changed the migration experience, offering new avenues for virtual modes of co-presence and potentially creating new functions and changes in the nature of family relationships (Bacigalupe and Lambe 2011; Baldassar 2008; Wilding 2006). As argued by Tarrant (2015), ICTs can facilitate a "space for intergenerational cohesion" but at the same time "exacerbate the emotional distance between generational groups" (295). However, there is still 
very limited knowledge about the impact of ICT-based communication on older peoples' social relations and well-being in transnational family settings. What meanings do older people attach to the use of ICTs? What factors facilitate or hamper their access and the use of ICTs? How are virtual and face-to-face co-presence related to each other?

Nedelcu (2016, in this issue) addresses these and other issues in her paper on transnational grandparenting practices of older Romanians with children and grandchildren in Canada and Switzerland. Based on data gathered through 101 qualitative interviews with high-skilled Romanian migrants and their parents, Nedelcu shows that migrants' parents are able to acquire manifold technological skills in order to cope with distance and separation and to improve the quality of their interaction and relationships with children and grandchildren living abroad. She further reveals how ICTs and cross-border mobility allow grandparents to take on their role as childcare providers across borders and develop new transnational lifestyles. The favorable integration of their children in their destination country offers the grandparents avenues to take on these new roles. These avenues, however, are blocked for migrants who lack the necessary resources to fulfill the requirements for visitors' visas or family reunification.

Altogether, the four papers provide insights into different aspects of transnational aging at the macro-level of politics, the meso-level of organizations and the micro-level of the family/individual. This special issue shows how transnational processes diffuse into different areas of life in old age (e.g., through policies) and are actively shaped by the older people themselves (e.g., through their everyday practices). The range of transnational aging phenomena addressed as well as the diverse methodological approaches add new dimensions to previous research in the field and illustrate the importance of (re-) reading existing - and collecting new - data from a transnational perspective.

\section{References}

Ackers L, Dwyer P (2002) Senior citizenship? Retirement, migration and welfare in the European Union. Policy Press, Bristol

Avato J, Koettl J, Sabates-Wheeler R (2010) Social security regimes, global estimates and good practices: the status of social protection for international migrants. World Dev 38(4):455-466. https://doi.org/10.1016/j.worlddev.2009.10.003

Bacigalupe G, Lambe S (2011) Virtualizing intimacy: information communication technologies and transnational families in therapy. Fam Process 50(1):12-26. https://doi. org $/ 10.1111 / \mathrm{j} .1545-5300.2010 .01343 . \mathrm{x}$

Baldassar L (2008) Missing kin and longing to be together: emotions and the construction of co-presence in transnational relationships. J Intercul Stud 2(3):247-266. https://doi. org/10.1080/07256860802169196
Baldassar L, Baldock C, Wilding R (2007) Families caring across borders: migration, ageing and transnational caregiving. Palgrave Macmillan, Basingstoke

Baldassar L, Wilding R, Boccagni P, Merla L (2017) Aging in place in a mobile world: new media and older people's support networks. Transnatl Soc Rev Soc Work J 7(1):2-9. https://doi.org /10.1080/21931674.2016.1277864

Baykara-Krumme H (2013) Returning, staying or both? Mobility patterns among elderly Turkish migrants after retirement. Transnatl Soc Rev Soc Work J 3(1):11-29. https://doi.org/10.1080/2193 1674.2013.10820745

Baykara-Krumme H, Motel-Klingebiel A, Schimany P (2012) Viele Welten des Alterns? Ältere Migrantinnen und Migranten in der Alter(n)s- und Migrationsforschung. Eine Einführung (Many Worlds of Ageing? Ageing Migrants in Ageing and Migration Research. An Introduction). In: Baykara-Krumme H, MotelKlingebiel A, Schimany P (eds) Viele Welten des Alterns? Ältere Migranten im alternden Deutschland (Many worlds of Aging? Aging Migrants in Ageing Germany). VS Verlag, Wiesbaden, pp 11-42

Bender D, Hollstein T, Horn V, Huber L, Schweppe C (2014) Old age care facilities and care-seeking elderly on the move. Transnatl Soc Rev Soc Work J 4(2/3):290-293. https://doi.org/10.1080/2 1931674.2014.964022

Bender D, Hollstein T, Schweppe C (2017a) Alteneinrichtungen für deutschsprachige Menschen in Thailand und Polen: "Alten-Export" oder erweiterte Lebensoptionen im Alter? (Old age facilities for German speaking older people in Thailand: "Elderly-export" or extended life option in old age?) Nachrichtendienst des Deutschen Vereins für öffentliche und private Fürsorge e.V. 97(10)

Bender D, Hollstein T, Schweppe C (2017b) The emergence of care facilities in Thailand for older German-speaking people. Structural backgrounds and facility operators as transnational actors. Eur J Ageing. https://doi.org/10.1007/s10433-017-0444-1

Berry JW (1980) Acculturation as varieties of adaptation. In: Padilla A (ed) Acculturation: theory, models and findings. Westview, Boulder, pp 9-25

Blaakilde E (2014) Where is "place" in aging in place? Transnational issues for the Danish state and its retirement migrants abroad. J Hous Elder 29(1/2):146-163. https://doi.org/10.1080/02763 893.2015.989773

Böcker A, Hunter A (2017) Legislating for transnational ageing: a challenge to the logics of the welfare state. Eur J Ageing. https:// doi.org/10.1007/s10433-017-0431-6

Bolzman C, Fibbi R, Vial M (2006) What to do after retirement? Elderly migrants and the question of return. J Ethn Migr Stud 32(8):1359-1375. https://doi.org/10.1080/13691830600928748

Bolzman C, Kaeser L, Christe E (2017) Transnational mobilities as a way of life among older migrants from southern Europe. Popul Space Place. https://doi.org/10.1002/psp.2016

Casado-Díaz M, Kaiser C, Warnes A (2004) Northern European retired residents in nine southern European areas: characteristics. Motiv Adjust Ageing Soc 24(3):353-381. https://doi. org/10.1017/S0144686X04001898

Chege N (2014) Male beach workers and western female tourists: livelihood strategies in Kenya's south coast region. Dissertation. Université de Lausanne. Faculté des Sciences Sociales et Politiques

Ciobanu O, Fokkema T, Nedelcu M (2017) Ageing as a migrant: vulnerabilities, agency and policy implications. J Ethn Migr Stud 43(2):164-181. https://doi.org/10.1080/13691 83X.2016.1238903

Deneva N (2012) Transnational aging carers: on transformation of kinship and citizenship in the context of migration among Bulgarian Muslims in Spain. Soc Polit 19(1):105-128 
Dwyer P, Papadimitriou D (2006) The social security rights of older international migrants in the European Union. J Ethn Migr Stud 32:1301-1319. https://doi.org/10.1080/13691830600927773

Faist T (2000) The volume and dynamics of international migration and transnational social spaces. Oxford University Press, Oxford

Glick Schiller N, Basch L, Szanton Blanc C (1992) Towards a transnational perspective in migration: race, class, ethnicity and nationalism reconsidered. New York Academy of Sciences, New York

Gustafson P (2008) Transnationalism in retirement migration: the case of north European retirees in Spain. Ethn Racial Stud 31(3):451475. https://doi.org/10.1080/01419870701492000

Hall K, Hardill I (2016) Retirement migration, the 'other' story: caring for frail elderly British citizens in Spain. Ageing Soc 36:562-585. https://doi.org/10.1017/S0144686X14001342

Hayes M (2015) Moving south: the economic motives and structural context of north America's emigrants in Cuenca, Ecuador. Mobilities 10(2):267-284. https://doi.org/10.1080/17450101.2013.858 940

Horn V, Schweppe C (2016) Transnational aging: current insights and future challenges. In: Horn V, Schweppe C (eds) Introduction: transnational aging - current insights and future challenges. Routledge, New York, pp 1-15

Horn V, Schweppe C, Um S (2013) Transnational aging — a young field of research. Transnatl Soc Rev 3(1):7-10. https://doi.org/10.1080 /21931674.2013.10820744

Horn V, Schweppe C, Bender D, Hollstein T (2016) "Moving (for) elder care abroad": the fragile promises of old-age care facilities for elderly Germans in Thailand. In: Horn V, Schweppe C (eds) Introduction: transnational aging - current insights and future challenges. Routledge, New York, pp 163-177

Husa K, Vielhaber C, Jöstl J, Veress K, Wieser B (2014) Searching for paradise? International retirement migration to Thailand-a case study of Hua Hin and Cha-am. In: Husa K, Trupp A, Wohlschlägl H (eds) Southeast Asian mobility transitions: issues and trends in migration and tourism, edition: Abhandlungen zur Geographie und Regionalforschung (Discussions on Geography and Regional Research), vol 19, Department of Geography and Regional Research, Vienna, pp 137-167

Khagram S, Levitt P (2008) The transnational studies reader. Routledge, New York

King R, Vullnetari J (2006) Orphan pensioners and migrating grandparents: the impact of mass migration on older people in rural Albania. Ageing Soc 26(5):783-816. https://doi.org/10.1017/ S0144686X06005125

King R, Warnes AM, Williams AM (2000) Sunset lives: British retirement migration to the Mediterranean. Berg, Oxford

Klok J, van Tilburg TG, Suanet B, Fokkema T, Huisman M (2017) National and transnational belonging among Turkish and Moroccan older migrants in the Netherlands: protective against loneliness? Eur J Ageing. https://doi.org/10.1007/s10433-017-0420-9

La Parra D, Angel MM (2008) Health status and access to healthcare of British nationals living on the Costa Blanca, Spain. Ageing Soc 28(1):85-102. https://doi.org/10.1017/S0144686X07006563

Lardiés-Bosque R, Guillén JC, Montes-de-Oca V (2016) Retirement migration and transnationalism in northern Mexico. J Ethn Migr Stud 42(5):816-833. https://doi.org/10.1080/13691 83X.2015.1086632

Leach MA (2008) America's older immigrants: a profile. Generations 32(4):34-39

Levitt P, Glick Schiller N (2004) Conceptualizing simultaneity: a transnational social field perspective on society. Int Migrat Rev 38(3):1002-1039. https://doi.org/10.1111/j.1747-7379.2004. tb00227.x

Lie MLS (2010) Across the oceans: childcare and grandparenting in UK Chinese and Bangladeshi households. J Ethn Migr Stud 36(9):1425-1443
Lunt N (2009) Older people within transnational families: the social policy implications. Int J Soc Welf 18(3):243-251. https://doi. org/10.1111/j.1468-2397.2008.00600.x

Mishra R (2000) Globalization and the welfare state. Edward Elgar Publishing, Cheltenham

Nedelcu M (2016) Transnational grandparenting in the digital age: mediated co-presence and childcare in the case of Romanian migrants in Switzerland and Canada. Eur J Ageing. https://doi. org/10.1007/s10433-017-0436-1

Nokielski H (2005) Transnationale Ruhestandsmigration (Transnational retirement migration). In: Drepper T, Nokielski H, Göbel A (eds) Sozialer Wandel und kulturelle Innovation (Social change and cultural innovation). Duncker \& Humblot, Berlin, pp 311-334

Ono M (2008) Long-stay tourism and international retirement migration: Japanese retirees in Malaysia. In: Yamashita S, Minami, M, Haines D, Eades W, Jerry S (eds) Transnational migration in East Asia. Japan in a comparative focus. Senri ethnological reports 77. National Museum of Ethnology, Osaka, pp 151-162

O'Reilly K (2000) The British on the Costa del Sol: transnational identities and local communities. Routledge, London

Philipson C, Ahmed N (2004) Transnational communities, migration and changing identities in later life: a new research agenda. In: Daatland S-O, Biggs S (eds) Ageing and diversity: multiple pathways and cultural migrations. Policy Press, Bristol, pp 157-174

Smith Nielsen S, Yazici S, Gronwald Petersen S, Blaakilde AL, Krasnik A (2012) Use of cross-border healthcare services among ethnic Danes, Turkish immigrants and Turkish descendants in Denmark: a combined survey and registry study. BMC Health Serv Res 12(390):1-10. https://doi.org/10.1186/1472-6963-12-390

Tarrant A (2015) (Grand) paternal care practices and affective intergenerational encounters using ICT's. In: Vanderbeck R, Worth N (eds) Intergenerational space. Routledge, London, pp 286-299

Torres S (2013) Transnationalism and the study of aging and old age. In: Phellas C (ed) Aging in European societies. International perspectives on aging, vol 6. Springer, Boston, pp 263-281. https:// doi.org/10.1007/978-1-4419-8345-9_18

Toyota M (2006) Ageing and transnational householding: Japanese retirees in southeast Asia. Int Dev Plan Rev 28(4):515-531. https://doi.org/10.3828/idpr.28.4.5

Toyota M, Xiang B (2012) The emerging transnational "retirement industry" in Southeast Asia". Int J Sociol Soc Policy 32(11/12):708-719. https://doi.org/10.1108/01443331211280737

Van Der Geest S, Mul A, Vermeulen H (2004) Linkages between migration and the care of frail older people: observations from Greece, Ghana and The Netherlands. Ageing Soc 24(3):431-450. https://doi.org/10.1017/S0144686X04002302

White P (2006) Migrant populations approaching old age: prospects in Europe. J Ethn Migr Stud 32(8):1283-1300. https://doi. org/10.1080/13691830600927708

Wilding R (2006) Virtual' intimacies? Families, communication across transnational contexts. Glob Netw 6(2):125-142. https://doi. org/10.1111/j.1471-0374.2006.00137.x

Wimmer A, Glick Schiller N (2002) Methodological nationalism and beyond: nation-state building, migration and the social sciences. Glob Netw 2(2):301-334. https://doi. org/10.1111/1471-0374.00043

Wong KM, Musa G (2015) International second home retirement motives in malaysia: comparing British and Japanese retirees. Asia Pac J Tour Res 20(9):1041-1062. https://doi.org/10.1080/ 10941665.2014.950303

Zhou YR (2012) Space, time, and self: rethinking aging in the contexts of immigration and transnationalism. J Aging Stud 26:232-242. https://doi.org/10.1016/j.jaging.2012.02.002

Zontini E (2015) Growing old in a transnational social field: belonging, mobility and identity among Italian migrants. Ethn Racial Stud 38(2):326-341. https://doi.org/10.1080/01419870.2014.885543 